\title{
KETUHANAN YANG BERKEBUDAYAAN \\ Menjadi Shaleh dalam Bingkai Kebudayaan
}

\author{
Alimuddin Hassan \\ Dosen UIN Suska Riau \\ Email: alimuddin@uin-suska.ac.id \\ Tuty Erdalina \\ Dosen UIN Suska Riau \\ Email: tuty.erdalina@gmail.com \\ Imam Hanafi \\ ISAIS UIN Suska Riau \\ Email: imam.hanafi@,uin-suska.ac.id
}

Abstrak:

Diantara perdebatan yang nyaris melabirkan pertikaian di negeri ini, adalah gagasan tentang sebuah klausul "Ketubanan yang Berkebudayaan" dalam Rancangan Undang-Undang Haluan Ideologi Pancasila (RUU HIP). Sebenarnya, sang penggagas, Soekarno, telah menyampaikan ini pada tabun 1945, ketika akan menetapkan Pancasila sebagai ideologi negara. Menurutnya, istilah itu, menegaskan babwa Indonesia tegak atas dasar kekuatan agama. Kekuatan relasi agama dan negara di Indonesia, sangat sinergis dan tidak ada jurang pemisah antara keduanya, sehingga Indonesia sering juga disebut dengan religious nation state atau negara kebangsaan yang dijiwai oleh agama yang berketuhanan, bukan agama yang bertuban. Di sini, sistem sosial politik dan kemasyarakat, ditopang oleh kesadaran akan nilai-nilai ketuhanan. Makna selanjutnya adalah bahwa seluruh warga bangsa harus mentransformasikan nilai-nilai ketubanan atau nilai-nilai spritualnya kedalam relasi berbangsa dan bernegara, dalam kehidupan sosial-kemasyatakatan, dalam ruang-ruang publik. Dari proses transformasi ini, lalu membudaya dan membentuk. karakter bangsa. Dalam situasi bangsa Indonesia yang heterogen, terdiri dari berbagai macam suku, babasa, dan agama, maka transformasi akan nilai-nilai universal ketubanan dari masing-masing agama, menjadi sangat penting untuk. lakukan.

Kata Kunci: Kesholehan, pancasila, ketuhanan yang berkebudayaan

Abstract:

Among the debates that almost gave rise to conflict in this country, was the idea of a clause "Cultivated Belief" in the Draft Law on the Path of Pancasila Ideology (RUU HIP). In fact, the initiator, Soekarno, had conveyed this in 1945, when he was about to establish Pancasila as the state ideology. According to him, the term emphasizes that Indonesia is established on the basis of religious power. The strength of the relationship between religion and the state in Indonesia is very synergistic and there is no gap between the two, so that Indonesia is often referred to as a religious nation state or a national state that is imbued with a divinity religion, not a godly religion. Here, the socio-political system and society are supported by an awareness of divine values. The next meaning is that all citizens of the nation must transform their divine values or spiritual values into national and state relations, in social-community life, in public spaces. From this transformation process, it becomes entrenched and forms the nation's character. In the heterogeneous situation of the Indonesian nation, consisting of various ethnic groups, languages, and religions, the transformation of the universal divine values of each religion becomes very important to do.

Keywords: Piety, Pancasila, cultured divinity

\section{PENDAHULUAN}

Beberapa bulan yang lalu, bangsa ini dihebohkan oleh adanya isu tentang pembahasan
Rancangan Undang-Undang Haluan Ideologi Pancasila (RUU HIP) yang dilakukan oleh Pemerintah dan Dewan Perwakilan Rakyat (DPR). 


\section{NUSANTARA; Journal for Southeast Asian Islamic Studies}

Vol. 17, No. 1, Juni 2021

Kontraversi muncul di tengah masyarakat. Demonstrasi di berbagai daerah mewarnai penolakan atas RUU tersebut. ${ }^{1}$ Dunia maya pun tidak tinggal diam, Wathsap (WA), Facebook (FB), tweeter dan lainnya ikut serta menyemarakkan 'gonjang-ganjing' perdebatan tersebut.

Setidaknya ada tiga isu utama, yan selalu dinarasikan sebagai sebuah penolakan atas RUU tersebut. Pertama, isu tentang TAP MPRS $\mathrm{XXV} / \mathrm{MPRS} / 1996$. TAP ini berisi tentang pembubaran dan pelarangan atas adanya Partai Komunis Indonesia (PKI) di Indonesia. ${ }^{2}$ Dalam TAP MPR ini juga menegaskan bahwa PKI adalah organisasi terlarang yang tidak boleh menyebarkan atau mengembangkan faham atau ajaran Komunis/Marxisme-Leninisme. Mereka yang menolak RUU HIP ini, menyayangkan atas tidak ditetapkannya TAP MPR tersebut dalam RUU. Seolah-olah negara sedang membuka ruang, bagi lahirnya ideologi Komunisme. ${ }^{3}$ Namun, sebagian yang lain berpendapat bahwa sebagai sebuah ideologi, ketetapan MPR sebenarnya tidak memiliki arti apa-apa. Ideologi Komunis bisa hidup dan berkembang kapan saja. Lawan dari ideologi ini adalah demokratisasi dengan Pancasila sebagai ideologinya. Selama hal itu tetap berjalan di bumi Indinesia, Komunisme tidak akan bisa hidup.

1 Aksi tersebut diantaranya dilakukan di Surabaya, Jakarta, Solo, Riau, Kalimantan Barat dan daerah lainnya, yang dilakukan oleh FKUB, MUI, FPI, PA 212, Gerakan Umat Islam Anti Komunis (Gamis), Forum Komunikasi Purnawirawan TNI-Polri.

2 PKI adalah Partai Komunis Indonesia dan pemenang pemilu di tahun 1955. PKI merupakan organisasi politik yang dianggap paling bertanggung jawab terhadap peristiwa 1 Oktobel 1965. Menurut versi resmi rezim Suharto, peristiwa tersebut adalah upaya kudeta gagal yang dilakukan oleh PKI, untuk mengganti ideologi Pancasila dan UUD dengan ideologi komunis. Lihat Budiawan, "Living with the Spectre of the Past: Traumatic Experiences among Wives of Former Political Prisoners of the ' 1965 Event' in Indonesia", dalam R. Waterson \& Kwok Kian-Woon (ed), Contestations of Memory in Southeast Asia, (Singapura: NUS Press, 2012), hlm. 273

${ }^{3}$ Dalam sejarah, Gus Dur sebagai Presiden waktu itu, pernah mengusulkan pembubaran TAP MPR ini, namun gagasan Gus Dur ditolek oleh MPR.

${ }^{4}$ Meskipun Soekarno sudah menyampaikan gagasan tentang Pancasila, kemudian beliau memeras Pancasila itu pada Trisila dan Ekasila,. Namun gagasan Pancasila itu kemudian menjadi Dasar Negara dalam Pembukaan UUD 1945. Karena ia menjadi dasar negara, maka rumusan inilah
Isu Kedua, berkaitan dengan penyerapan atau diperasnya lima dasar (Pancasila) kepada tiga (Trisila) dan satu dasar (Ekasila). Trisila itu adalah (1). Socio-nationalism (perasan dari kebangsaan dan kemanusiaan); (2). Socio-democratie (perasan dari keadilan sosial dan kerakyatan); dan (3). Ketuhanan. Sedangkan Ekasila adalah "gotong royong." Dalam sejarah, proses itu dilakukan oleh Soekarno sendiri ketika menyampaikan gagasan tentang Pancasila. ${ }^{5}$ Menurut Suwarno, kelima sila itu berasal dari prinsip yang terkandung dalam satu perkataan Indonesia yang tulen, yakni gotong royong. ${ }^{6} \mathrm{Hal}$ ini menunjukkan bahwa Soekarno memiliki pemahaman yang sangat mendalam tentang Indonesia, yaitu sebuah bangsa yang hidup dan berkembang dalam lingkup sejarah, peradaban, agama, dan lainnya dengan semangat gotong royong. ${ }^{7}$ Dalam istilah Supomo, sebagai negara integralistik, yakni negara bersatu dengan seluruh rakyat dan mengatasi segala kepentingan kelompok atau golongan. ${ }^{8}$ Sebagaimana argumentasi yang disebutkan oleh Soekarno berikut ini:

"Kita mendirikan negara Indonesia... semua buat semua! Bukan Kristen buat Indonesia, bukan Islam buat Indonesia,....tetapi Indonesia buat Indonesia, semua buat

yang dipakai secara resmi sebagai fondasi Indonesia merdeka. Jika fondasi ini diganti, maka runtuhlah bangunan Indonesia. Mengenai hal ini, Boelars mengatakan bahwa meskipun UUD 1945 sudah menetapkan Pancasila sebagai dasar negara, masih juga ada pihak yang hendak mengganti Pancasila dengan dasar lain. Lihat Huub. J.W.M. Boelaars, Indonesianisasi, (Yogyakarta: Kanisius, 2009), hlm. 147

${ }^{5} \mathrm{M}$. Yamin dalam salah satu tulisannya menyatakan bahwa lahirnya Pancasila berasal dari Soekarno, yaitu pada 1 Juni 1945. Lihat Muhammad Yamin, Pembabasan UndangUndang Dasar Republik. Indonesia, di Cipanas-Rumah Siguntang, 29 Mei 1960, hlm. 289

6 P.J. Suwarno, Pancasila Budaya Bangsa Indonesia (Penelitian Pancasila dengan Pendekatan Historis, Filosofis, dan Sosio-Yuridis Kenegaraan). (Yogyakarta: Kanisius, 1993), hlm. 5

${ }^{7}$ Meskipun sesungguhnya menurut Sunoto, usulan tentang "gotong royong" itu, hanyalah sekedar usulan semata. Menurutnya tidak lah logis, jika Pancasila kemudian diperas menjadi kata "Gotong Royong". Karena setiap sila tidak harus memiliki semangat gotong royong. Misalnya sila Ketuhanan Yang Maha Esa, tidak ada korelasinya dengan gotong royong. Lihat Sunoto, Mengenal Filsafat Pancasila: Pendekatan melalui Metafisika, Logika, dan Etika, (Yogyakarta: Hanindita, 2000), hlm. 93

${ }^{8}$ Suwarno, op. cit, hlm. 40 
semua! .... Negara yang kita dirikan haruslah negara gotong royong!"’

Terkait dengan pernyataan itu, Dewantara memberikan catatan;

Kembali kepada Soekarno, dengan mengatakan bahwa prinsip negara ini adalah gotong royong, ia mau mengatakan bahwa tidak boleh ada lagi klaim-klaim golongan, pribadi, dan kelompok apapun yang hendak memperjuangkan kepentingan mereka sendiri di atas kepentingan bersama. Artinya, sebenarnya tidak boleh ada klaim mayoritas atas minoritas! Tidak boleh ada klaim warga pribumi atas peranakan! Tidak boleh ada klaim kaum kaya atas kaum miskin! Mengapa? Karena, kalau ada klaim-klaim tersebut, untuk apa ada Indonesia merdeka? Bukanlah semua itu bentuk dominasi dan penjajahan baru? Lebih dari itu, dengan mengatakan gotong royong adalah prinsip dasar negara Indonesia Soekarno hendak mengatakan bahwa Indonesia didirikan untuk menjamin kepentingan semua warga Indonesia, apapun agamanya, golongannya, sukunya, dan keadaan ekonominya. Dalam retorika, ia mengecam "individualisme" yang lahir dari liberalisme Barat. Individualisme itu melahirkan egoisme, dan ini terutama dicerminkan oleh pertarungan antarpartai. ${ }^{10}$

Isu Ketiga, adalah munculnya klausul "Ketuhanan yang Berkebudayaan". Diantara alasan penolakan atas adanya klausul ini, adalah bahwa kata "ketuhanan yang Berkebudayaan" itu, disampaikan oleh Soekarno pada 1 Juni 1945 dan kemudian dimatangkan dengan "Ketuhanan yang Maha Esa". Oleh karena itu, mereka menyatakan:

"Ini sudah kesepakatan kita sampai sekarang, maka terkejutlah kami khusus Majelis Ulama Indonesia terkejut ada usaha

9 Sekretariat Negara Republik Indonesia, Risalah Sidang Badan Penyelidik Usaha-Usaha Persiapan Kemerdekaan Indonesia (BPUPKI), (Jakarta.1995), hlm. 617

10 Agustinus W. Dewantara, "Alangkah Hebatnya Negara Gotong Royong” (Indonesia dalam Kacamata Soekarno), (Yogyakarta: Kanisius, 2017), hlm. 17.

11 Pernyataan Wasekjen MUI, Ustaz Tengku Zulkarnain, ketika ikut demonstrasi menolak RUU Haluan Ideologi Pancasila (HIP). Lihat https://news.detik.com/berita/d-5079045/demo-tolak- memeras Pancasila, Trisila, Ekasila dan Ketuhanan Yang Maha Esa-nya itu diperkosa menjadi Ketuhanan Yang Berkebudayaan. Ini luar biasa ini, ini bagi kami kaum muslimin tamparan keras ini. Sehingga seluruh MUI se-Indonesia 34 Provinsi tanda tangan. Tidak pernah, tidak pernah, kecuali Munas atau Rakernas ada keputusan pusat yang ditandatangani seluruh pimpinan pusat,"11

Jadi ada anggapan bahwa Ketuhanan yang Maha Esa itu, "diperkosa" dengan menjadi Ketuhanan yang Berkebudayaan. Apa sesungguhnya makna Ketuhanan yang Berkebudayaan itu? Kesalehan seperti apa yang selaras dengan nilai-nilai Ketuhanan yang Berkebudayaan dalam konteks hari ini? Tulisan ini mencoba menjawab persoalan itu, dan tidak melihat aspek historis dari kemunculan istilah tersebut. Konsep dasarnya adalah bahwa bangsa Indonesia ini lahir dan tumbuh-berkembang dalam nilai-nilai agama yang selaras dengan kebudayaan bangsa Indoensia itu sendiri, mengedepankan budhi dan toleransi. ${ }^{12}$

\section{Berebut Shaleh; Pertarungan Epistemologis}

Menjelaskan konsep shaleh dalam Islam, sesungguhnya sama dengan menjelaskan doktrindoktrin ajaran sebanyak aliran atau faham dalam Islam itu sendiri. ${ }^{13}$ Selain itu juga, tidak jarang penjelasan tentang kesalehan ini, mengandung makna politis. Artinya, muslim di Iran dan muslim di Arab Saudi misalnya, ketika memaknai kesalehan akan berbeda-beda. ${ }^{14}$

Secara normatif, kata saleh, merupakan derivasi dari kata $s a-l u$-ha yang bermakna "baik"

ruu-hip-tengku-zul-ketuhanan-berkebudayaan-tak-bakalterjadi

12 Yudi Latif, Negara Paripurna: Historitas, Rasionalitas, dan Katualitas, (Jakarta: PT. Gramedia Pustaka Utama, 2017), hlm. 16

13 Thomas B. Pepinsky, R. William Liddle, dan Saiful Mujani, Kesalehan dan Pilihan Politik; Memahami Kebangkitan Islam-Politik dari Perspekti Indonesia, (Jakarta: Prenada, 2018), hlm. 30

$$
{ }^{14} \text { Ibid }
$$




\section{NUSANTARA; Journal for Southeast Asian Islamic Studies}

Vol. 17, No. 1, Juni 2021

dan menjadi lawan dari kata "rusak". ${ }^{15}$ Atau jika merujuk pada akar kata salaha kemudian menghasilkan bentuk kata sulhan dan yaslahu, maka kata saleh akan bermakna "berhentinya sesuatu dari kerusakan dan berubah menjadi baik dan manfaat". ${ }^{16}$ Makna ini, kemudian mendorong kepada para ahli tafsir kepada pengertian bahwa perbuatan baik yang dipandang oleh agama dan manusia. ${ }^{17}$

Dalam Islam, kata shaleh berdampingan dengan amal, yaitu amal shaleh. Shaleh dengan begitu bermakna "gerak" atau aktivitas yang baik. M. Quraish Shihab memaknai amal saleh sebagai amal yang diterima dan dipuji oleh Allah swt. ${ }^{18}$ Sedangkan Syekh Muhammad al-Ghazali, dalam Al-Musykilat fi al-Thariq al-Hayah al-Islamiyyah, mengartikan amal saleh dengan "setiap usaha keras yang dikorbankan buat berkhidmat terhadap agama". ${ }^{19}$

Secara semantik, kata 'amal berasal dari bahasa Arab, yang berarti pekerjaan. Kata ini searti dengan kata $a l-f i^{\prime} l .{ }^{20}$ Perbedaan antara keduanya adalah jika kata 'amal biasanya digunakan untuk menggambarkan suatu aktivitas yang dilakukan dengan sengaja dan maksud tertentu, maka yang disebut terakhir digunakannya untuk menjelaskan suatu pekerjaan, baik yang disengaja maupun tidak. ${ }^{21}$

Berdasarkan hal itu, maka sewajarnya jika konsekuensi dari kesalehan seseorang ditimbang dari sejauhmana ia dapat memberikan manfaat atau berguna bagi agama dan sesamanya, bahkan alam semesta. Artinya, saleh sangat berkait erat dengan dimensi keimanan pada Tuhan, berkaitan dengan ucapan dan tingkah laku dalam kehidupan

15 Ahmad Ibnu Faris bin Zakariyya, mu'jam maqayis allugah, $1392 \mathrm{H}-1972 \mathrm{H}$, hlm 145. Lihat juga dalam tafsir Tabari (Maktabah Syamilah no 1428). Pengertian dasar ini disebabkan oleh karena dalam beberapa ayat yang bercerita tentang amal saleh (yang bergandengan dengan kata iman) selalu bergandengan dengan ayat yang menjelaskan tentang aktifitas kafir (yang merusak).

${ }^{16}$ Yusran, "Amal Saleh: Doktrin Teologi dan Sikap Sosial", dalam Jurnal Al-Adyaan, Vol. I, No. 2, (Desember 2015), hlm. 127

${ }^{17}$ Dindin M Saepuddin, M. Solahuddin, dan Izzah Faizah Siti Rusydati Khairani, "Iman dan Amal Saleh Dalam Al-Qur'an (Studi Kajian Semantik)." Dalam Jurnal Al-Bayan, Vol 1, No.2 (Juni 2017), hlm. 17 sehari-hari sesama manusia, serta dengan alam semesta. ${ }^{22}$

Problemnya kemudian adalah terkait dengan doktrin "kesia-siaan" bagi mereka yang melakukan kesalehan, tanpa diimbangi dengan keimanan. Misalnya di dalam al-Quran bahwa kesia-siaan perbuatan seseorang itu selalu dikaitkan dengan keimanannya (QS. Al-Baqarah/2:258), dan lebih sulit lagi adalah kesia-kesiaan tersebut menimpa bagi mereka yang dianggap "kafir" seperti pada QS. Ibrahim/14:18 dan QS. al-Nur/24: 39, QS. Al-Maidah/5:54, QS. Al-Baqarah/2;217, QS. Ali Imran/3;22, QS. Al-Maidah/5;53, dan QS. Altawbah/9;7). Implikasinya adalah bahwa secara teologis, mereka yang tidak memiliki iman yang sama dengan Islam, maka amal saleh-nya dianggap tidak bermakna.

Namun demikian, apa yang disampaikan oleh al-Quran tersebut sesungguhnya merupakan pernyataan bahwa iman itu selalu bergandengan dengan dengan amal saleh dan kafir itu bergandengan dengan amal buruk. Amal saleh idealnya selalu berbuah manfaat bagi kehidupan dunia (QS. An-Nahl/16;97) dan amal buruk itu selalu berujung kepada kerusakan. Maknanya adalah siapapun yang berbuat baik di alam semesta ini, maka akan dicatat sebagai amal saleh, sebaliknya yang melakukan pengrusakan dan kezaliman, maka ia akan dianggap sebagai perilaku "kafir", perilaku yang sangat dibenci Tuhan.

Oleh karena itu, menjadi sangat penting bagi kita semua, sebagai sebuah negara bangsa yang sangat majmuk ini, untuk mengedepankan prinsip fastabiqul khairaat, berlomba-lomba dalam

${ }^{18}$ M. Quraish Shihab, Tafsir Al-Quran alKarim: Tafsir Atas Surat-Surat Pendek Berdasarkan Urutan Turunnya Wabyu, (Bandung: Pustaka Hidayah, 1997), h. 753.

${ }^{19}$ Syekh Muhammad al-Ghazali, dalam Al-Musykilat fi al-Thariq al-Hayah al-Islamiyyah, terj. Abdurrosyad Shiddiq, (Solo: Pustaka Mantiq, 1991), h. 20.

${ }^{20}$ Selain 'amal dan fi'l, kata-kata berikut juga memilki arti yang sama dengan kedua term tersebut, yaitu: al-sa'yu, alshan', al-iqtiraf dan al-jarah. Uraian tentang keenam term ini, dapat dibaca lebih lanjut dalam Jalaluddin Rahmat, Konsep Perbuatan Manusia Menurut al-Quran: Suatu Kajian Tafsir Tematik, (Jakarta: Bulan Bintang, 1992)

${ }^{21}$ M. Qurasih Shihab, op. cit., h. 752.

22 Fachruddin H S, Ensklopedia al-Qur"an, Jilid.1(Jakarta: Rineka Cipta, 1992), 95 
kebaikan. ${ }^{23}$ Setiap orang yang memiliki tradisi agama dan keyakinannya, didorong untuk selalu berinteraksi secara positif, saling menghormati dan saling bahu-membahu dalam menebar kasih sayang. Sebagaimana yang dikemukakan oleh Gus Dur, "Tidak penting apa pun agama atau sukumu. Kalau kamu bisa melakukan sesuatu yang baik untuke semua orang, orang tidak pernah tanya apa agamamu". $\mathrm{Nah}$, berbuat baik (amal saleh) yang berorientasi kepada kemanusiaan ini lah yang perlu ditonjolkan dalam konteks ini.

\section{Menjadi Shaleh; Antara Budbi dan Toleransi}

Negara Kesatuan Republik Indonesia yang kita diami ini, merupakan negara yang memiliki jumlah penduduk lebih dari 200 juta jiwa, dengan 17.800 pulau kecil dan besar. Menurut data Badan Pusat Statistik (BPS) Republik Indonesia pada tahun 2000, menyebutkan bahwa jumlah suku di Indonesia, yang berhasil terdata sebanyak 1.128 suku bangsa, dengan komposisi 1.072 etnik dan sub-etnik di Indonesia. Sementara, menurut hasil penelitian Indonesia memiliki sekitar 743 bahasa. ${ }^{24}$ Dari jumlah itu, 442 bahasa sudah dipetakan oleh Badan Pengembangan dan Pembinaan Bahasa, sebanyak 26 bahasa diantaranya ada di Sumatera, 10 bahasa di Jawa dan Bali, 55 bahasa di Kalimantan, 58 bahasa di Sulawesi, 11 bahasa di Nusa Tenggara Barat, 49 bahasa di Nusa Tenggara Timur, 51 bahasa di Maluku, serta 207 bahasa di Papua. Kondisi ini, menempatkan Indonesia sebagai sebuah negara dengan tingkat pluralitas atau heterogenitas budaya yang sangat tinggi.

${ }^{23}$ Lihat QS. al-Maidah [5]: 48., QS. Al-Baqarah/2: 148

24 Sebagaimana dikemukakan oleh Wakil Menteri Pendidikan dan Kebudayaan Windu Nuryanti (2012), lihat http://www.menkokesra.go.id

25 Patut disadari, bila pluralism diletakkan pada wilayah teologis, maka akan melahirkan kelompok puritan teologis yang akan selalu mengakui bahwa agamanya adalah yang paling benar dan memahami ajarannya secara literlek yang kemungkinan besarnya akan turut mengkafirkan ummat lain yang berbeda agama. Lebih jelas baca, Abdullah Saeed, Pemikiran Islam: Sebuah Pengantar, terj (Yogyakarta: Kaukaba, 2014), 264-266

26 Heru Nugroho, Menumbubkan Ide-ide Kritis (Yogyakarta: Pustaka pelajar, 2001), 174

27 Budhy Munawar Rahman, Islam Pluralis: Wacana Kesetaraan Kaum Beriman (Jakarta: Paramadina, 2001), 46-48
Secara sosiologis, adanya pluralisme tersebut menjadi modal sosial untuk mengarahkan konsep pluralisme tidak hanya pada tataran teologis an sich. ${ }^{25}$ Melainkan meletakkannya kepada wilayah ideologis dengan mengejawantah pada etika sosial dalam kehidupan yang heterogen. Sehingga, pluralisme ditegakkan sebagai cara pandang dalam melihat orang lain sebagai bagian dari sistem sosial yang harus dihargai. ${ }^{26}$ Dan pluralisme digunakan sebagai dasar pemahaman yang inklusif dalam menentukan pandangan kita terhadap agamaagama lain. Dengan demikian, akan bisa arif melihat setiap perbedaan yang ada di dalam kemajemukan, dan bisa jadi akan memotivasi antara satu dengan yang berbeda untuk saling berlomba menuju kebaikan. ${ }^{27}$

Namun demikian, banyak ahli menghawatirkan keindahan Indonesia tersebut, akan tergerus oleh adanya globalisasi, yang terus menyuguhkan ruang tegangan (cultural tension). Dunia global yang disertai dengan gelombang teknologi informasi, membuat interaksi antar manusia menjadi tidak ada lagi jarak dan berlangsung secara terbuka. ${ }^{28}$ Pada aras ini, orang berkomunikasi hanya melalui aneka simbol yang berupa huruf dan angka. Berbagai narasi destruktif, "hilir-mudik" mewarnai ruang-ruang informasi bangsa ini. ${ }^{29}$ Selain itu, Martin van Bruinessen dalam bukunya mensinyalir akan adanya consrvative turn bagi masyarakat Indonesia, yaitu masyarakat yang tidak lagi suka akan kehadiran rumah-rumah ibadah baru di sekiarnya, bahkan bangsa ini sudah tidak mau lagi dengan adanya perbedaan. Perbedaan dianggap sebagai ancaman, dan kekerasan merupakan satu-satunya

28 Agustina Zubair, "Fenomena Facebook: Keterlibatan Teknologi Komunikasi dalam Perkembangan Komunikasi Manusia", dalam Jurnal ASPIKOM, vol. 1:1, (Juli, 2010), hlm. 6

${ }^{29}$ Hasil riset yang dilakukan oleh Forum Masyarakat Sipil dan Media Bali 2018 (BCSMF 2018) menggambarkan secara baik bagaimana demokrasi semakin memperoleh tatangan yang begitu kuat dari populisme dan politik identitas, yang justru dilahirkan dari proses komunikasi dunia maya. Tulisan Andina Dwifatma dalam buku ini, menjelaskan bagaimana peran media dalam memproduksi semangat populisme, yang justru membahayakan toleransi dan menumbuh-suburkan perilaku-perilaku derstruktif. Dinna Wisnu (Ed), Populisme, Politik Identitas dan Erosi Demokerasi di Abad ke-21; Refleksi dari Forum Masyarakat Sipil dan Media Bali 2018, (Jakarta: Friedrich-Ebert Stiftung (FES), 2019), hususnya pada halaman $35-42$. 


\section{NUSANTARA; Journal for Southeast Asian Islamic Studies}

Vol. 17, No. 1, Juni 2021

solusi untuk menyelesaikan perbedaan itu. ${ }^{30}$ Prediksi lain yang cukup mengejutkan lagi adalah riset yang dilakukan oleh Centre for Strategic and International Studies (CSIS). Riset ini, memberikan catatan bahwa masa depan isu tentang keagamaan, penuh diwarnai oleh persebaran konflik dan polapola radikalisme. ${ }^{31}$

Berdasarkan hal itu semua, maka banyak orang kemudian melirik kembali pada Pancasila sebagai hasil dari kesepakatan (konsesus) para pendiri bangsa ini, untuk dijadikan sebagai pilar utama dalam berbangsa. Pancasila sebagai konsensus kebangsaan yang sudah final itu, semestinya menjadi ruh bagi setiap interaksi warga bangsa. Sebagaimana Muhammadiyah yang menjadikan Pancasila sebagai Dar al- 'Ahd wa alSyahadah, sebagai sebuah konsensus nasional dan tempat bersaksi (dar al-Abdi), konsekuensinya Muhammadiyah memacu diri (fastabiqul khairot, berlomba-lomba dalam kebaikan) untuk ikut mengisi dan berbuat (wa al-Syahadab).

Pernyataan Ketuhanan yang Maha Esa juga menjadi perlambang bagi adanya konsensus bersama bahwa masyarakat Pancasila yang sejak dulu memang memiliki berbagai konsep tentang Tuhan, dipadukan menjadi Tuhan yang Maha Esa. Dengan begitu, maka kehidupan keagamaan masyarakat Pancasila, ditandai oleh kerelaan menerima keragaman sebagai kewajaran oleh penduduk Nusantara. Kerelaan juga berarti kesadaran bahwa Tuhan hadir dalam sejarah perkembangan kebangsaan Indonesia. ${ }^{32}$

Ketuhanan yang seperti itu lah sesungguhnya Ketuhanan yang lahir dari proses rekonsiliasi dan harmonisasi dari berbagai tradisi dan keyakinan, yang disebut sebagai Ketubanan gotong-royong. ${ }^{33}$ Istilah ini kemudian diperjelas oleh Soekarno

${ }^{30}$ Martin van Bruinessen, dkk, CONSERV ATIVE TURN: Islam Indonesia dalam Ancaman Fundamentalisme, Bandung: Mizan, 2014), hlm. 27-30

31 Shafi ah F. Muhibat(ed), Untuk Indonesia 2014-2019: Agenda Sosial-Politik dan Keamanan, (Jakarta: CSIS, 2014), hlm. $75-93$

32 Oleh Sumardjo disebutkan ini lah keunikan sistem ketuhanan dalam berbangsa di Indonesia, bahwa Tuhan yang banyak, dipersatukan kedalam yang Tunggal. Artinya, "Tuhan" Indonesia merupakan keutuhan kosmis yang menyatukan, merekonsiliasi, dan mengharmonisasi semua polarisasi kembali kepada yang Tunggal. Jacob Sumardjo, Arkeologi Budaya Indonesia: Pelacakan Hermeneutis-Historis sebagai "ketuhanan yang berkebudayaan", yaitu proses menyembah Tuhan dengan mengedepankan sifat toleransi, solidaritas, dan keterbukaan. Nilai-nilai itu kemudian menjadi dasar kesalehan dan diritualkan serta diamalkan oleh setiap agama yang ada di Indonesia, baik Islam, Kristen, dan agama-agama lainnya, dengan cara beradab dengan saling hormat-menghormati, saling menyayangi, dan saling mengayomi satu sama lain. ${ }^{34}$

Karena semua warga bangsa ini mengakui akan eksistensi yang Ilahi (Divine), dibentuk dari proses penyatuan yang beragam (Bhinika Tunggal Ika), maka sesungguhnya mereka juga meyakini bahwa semua manusia di bumi Indonesa adalah sama, setara. Bagi Tuhan, manusia diciptakan dalam kesetaraan. Tidak ada yang lebih mulia atau lebih terhormat dengan yang lainnya. Dalam konsep keindonesiaan, terdapat keluhuran berupa kemerdekaan dan kesetaraan manusia Indonesia, apa pun latar belakang sosial, kesukuan, dan keagamaannya. Ini suatu kenyataan yang sangat emansipatif, anti-diskriminatif, anti-majorokratik, suatu kenyataan yang sangat ilahi. ${ }^{35}$ Karena bertuhan berarti harus memelihara solidaritas antarmanusia, antara lain dalam memperjuangkan pembebasan dari ketidakadilan dan penderitaan manusia lain dan alam. ${ }^{36}$ Dengan bertuhan di bumi Indonesia, berarti saling membuka diri untuk mendahulukan etika dan budhi pekerti serta toleransi di atas kepentingan pribadinya atau bahkan agamanya sendiri. Sebagaimana cita-cita yang disampaikan Soekarno pada Sidang BPUPKI 1 Juni 1945, yaitu

Saudara-saudara yang bernama kaum kebangsaan di sini, maupun saudara-saudara yang dinamakan kaum Islam, semuanya telah mufakat, bahwa bukan negara demikian itulah

terhadap Artefak-Artefak Kebudayaan Indonesia, (Yogyakarta: Qalam, 2002), hlm. 9-10.

33 Yudi Latif, Negara Paripurna: Historisitas, Rasionalitas, dan Aktualitas Pancasila, (Jakarta: Gramedia, 2011), hlm. 115, 119,612

34 Donny Gahral Adian, "Radikalisme dan Pancasila”, dalam Kompas, 14 Januari 2017

35 John A. Titaley,"Mengembangkan Sumber Daya Gereja untuk Meningkatkan Pelayanan dan Kesaksian yang Mendatangkan Damai Sejahtera di Tengah dan Bersama Masyarakat", dalam John C. Simon (ed.), Melangkah pada Jalan Damai Sejabtera, (Jakarta: BPK Gunung Mulia, 2016)

36 Yudi Latif, Negara Paripurna, hlm. 115-116 
Alimuddin, dkk: Ketubanan yang Berkebudayaan...

kita punya tujuan. Kita hendak mendirikan suatu negara 'semua buat semua'. Bukan buat satu orang, bukan buat satu golongan, baik golongan bangsawan, maupun golongan kaya, tetapi semua buat semua. ${ }^{37}$

\section{Penutup}

Diantara perdebatan yang nyaris melahirkan pertikaian di negeri ini, adalah gagasan tentang sebuah klausul "Ketuhanan yang Berkebudayaan" dalam Rancangan Undang-Undang Haluan Ideologi Pancasila (RUU HIP). Sebenarnya, sang penggagas, Soekarno, telah menyampaikan ini pada tahun 1945, ketika akan menetapkan Pancasila sebagai ideologi negara. Rumusan tentang Pancasila sebagai dasar Negara ini, sesungguhnya sangat jelas. Pancasila sendiri dibangun dan berdiri tegak meupakan refleksi dari kekuatan relasi antar agama dan keyakinan, yang tumbuh subur sejak zaman Bangsa ini belum terbentuk, melalui proses harmonisasi dengan berbagai sistem ketuhanan. Kekuatan relasi agama dan negara di Indonesia, sangat sinergis dan tidak ada jurang pemisah antara keduanya, sehingga Indonesia sering juga disebut dengan religious nation state atau negara kebangsaan yang dijiwai oleh agama yang berketuhanan.

Di sini, sistem sosial politik dan kemasyarakat, ditopang oleh kesadaran akan nilai-nilai ketuhanan. Dalam situasi bangsa Indonesia yang heterogen, terdiri dari berbagai macam suku, bahasa, dan agama, maka menjunjung tinggi nilainilai toleransi dan mengedepankan budhi bekerti yang luhur, menjadi kekuatan yang penting untuk menegakkan kembali Pancasila dalam kehidupan kita sehari-hari.

\footnotetext{
${ }^{37}$ Sekretariat Negara Republik Indonesia, hlm. 71
} 


\section{DAFTAR KEPUSTAKAAN}

Abdullah Saeed, Pemikiran Islam: Sebuah Pengantar, terj (Yogyakarta: Kaukaba, 2014)

Agustina Zubair, "Fenomena Facebook: Keterlibatan Teknologi Komunikasi dalam Perkembangan Komunikasi Manusia", dalam Jurnal ASPIKOM, vol. 1:1, (Juli, 2010)

Agustinus W. Dewantara, "Alangkah Hebatnya Negara Gotong Royong" (Indonesia dalam Kacamata Soekarno), (Yogyakarta: Kanisius, 2017).

Budiawan, "Living with the Spectre of the Past: Traumatic Experiences among Wives of Former Political Prisoners of the '1965 Event' in Indonesia', dalam R. Waterson \& Kwok Kian-Woon (ed), Contestations of Memory in Southeast Asia, (Singapura: NUS Press, 2012)

Budhy Munawar Rahman, Islam Pluralis: Wacana Kesetaraan Kaum Beriman (Jakarta: Paramadina, 2001)

Dindin M Saepuddin, M. Solahuddin, dan Izzah Faizah Siti Rusydati Khairani, "Iman dan Amal Saleh Dalam Al-Qur'an (Studi Kajian Semantik)." Dalam Jurnal Al-Bayan, Vol 1, No.2 (Juni 2017)

Dinna Wisnu (Ed), Populisme, Politik Identitas dan Erosi Demokrasi di Abad kee-21; Refleksi dari Forum Masyarakat Sipil dan Media Bali 2018, (Jakarta: Friedrich-Ebert Stiftung (FES), 2019)

Donny Gahral Adian, "Radikalisme dan Pancasila", dalam Kompas, 14 Januari 2017

Fachruddin H S, Ensklopedia al-Qur"an, Jilid.1(Jakarta: Rineka Cipta, 1992)

Heru Nugroho, Menumbubkan Ide-ide Kritis (Yogyakarta: Pustaka pelajar, 2001)

Huub. J.W.M. Boelaars, Indonesianisasi, (Yogyakarta: Kanisius, 2009)
Jacob Sumardjo, Arkeologi Budaya Indonesia: Pelacakan Hermeneutis-Historis terhadap Artefak-Artefak Kebudayaan Indonesia, (Yogyakarta: Qalam, 2002)

John A. Titaley,"Mengembangkan Sumber Daya Gereja untuk Meningkatkan Pelayanan dan Kesaksian yang Mendatangkan Damai Sejahtera di Tengah dan Bersama Masyarakat", dalam John C. Simon (ed.), Melangkah pada Jalan Damai Sejabtera, (Jakarta: BPK Gunung Mulia, 2016)

Martin van Bruinessen, dkk, CONSERV ATIVE TURN: Islam Indonesia dalam Ancaman Fundamentalisme, (Bandung: Mizan, 2014)

Muhammad Yamin, Pembahasan Undang-Undang Dasar Republik Indonesia, di CipanasRumah Siguntang, 29 Mei 1960,

P.J. Suwarno, Pancasila Budaya Bangsa Indonesia (Penelitian Pancasila dengan Pendekatan Historis, Filosofis, dan Sosio-Yuridis Kenegaraan). (Yogyakarta: Kanisius, 1993)

Sekretariat Negara Republik Indonesia, Risalah Sidang Badan Penyelidik Usaha-Usaha Persiapan Kemerdekaan Indonesia (BPUPKI), (Jakarta.1995)

Sunoto, Mengenal Filsafat Pancasila: Pendekatan melalui Metafisika, Logika, dan Etika, (Yogyakarta: Hanindita, 2000),

Shafi ah F. Muhibat(ed), Untuk Indonesia 20142019: Agenda Sosial-Politik dan Keamanan, (Jakarta: CSIS, 2014)

Thomas B. Pepinsky, R. William Liddle, dan Saiful Mujani, Kesaleban dan Piliban Politik; Memahami Kebangkitan Islam-Politik dari Perspekti Indonesia, (Jakarta: Prenada, 2018)

Yusran, "Amal Saleh: Doktrin Teologi dan Sikap Sosial", dalam Jurnal Al-Adyaan, Vol. I, No. 2, (Desember 2015)

Yudi Latif, Negara Paripurna: Historisitas, Rasionalitas, dan Aktualitas Pancasila, (Jakarta: Gramedia, 2011) 